\title{
Local Wisdom of Settlement Growth in theUrban Fringe Areas
}

\author{
Bambang Setioko \\ Department of Architecture-Faculty of Engineering-Diponegoro University-Indonesia \\ keliek2000@yahoo.com
}

\begin{abstract}
The population growth in the urban fringe area of developed countries is dominated by the urban sprawl and followed by "white flight phenomena". In Indonesia, although the physically growth of settlements is similar, but the socially one is different. The modern housing estates have been built in the next to the rural settlements. In addition, the autonomous settlements have been emerged surrounding housing estates; the spread settlements will integrate in the following years. This research has been done with the qualitative methods and successfully revealing the existence of local wisdomof settlement growth in Semarang fringe area.
\end{abstract}

Keywords: fringe area, urban sprawl, white flight, local wisdom

\section{Introduction}

During the last decade, the growth of city's fringe area is becoming the worldwide phenomena. This development is dominated by the urban sprawl that changing the rural and agriculture areas into the building areas. A City grows wider continously, becoming the borderless city. This phenomena appears not only in the developed countries, but also in the developing countries. The increasing number of population particularly in the urban area of North American is followed by "White flight" phenomena; the exodus whites middle class migrating from the city center to the fringe areas, seeking better life for their chldren and safer neighborhoods. This situation might be a trigger of social segregation which lead to the social conflict. The development of fringe area indicated the destructive character both socially and physically.

The growth of fringe area in Indonesia is dominated by progressive urban sprawl development pattern. This pattern appears in a metropolitan city as well as in a small town. Semarang city, owned more than 1.5 million population seems indicate a similar phenomena. The affordable of land prices in the urban fringe areas becoming the main reason for many developers to build new housing estates, and the urban fringe is continously hustle growing. The modern housing estates have been built next to the traditional rural settlement. In addition, the autonomous settlements have been emerged surrounding planned settlement; those are taking the advantages of urban infrastructure that has been built previously by developer. This condition lead to the heterogeneous urban fringe areas with unstructured spatial pattern, which are consists of archipelago enclaves. The spreading settlements will integrate in the future. The integration pattern of urban space will determine the future city shape. 


\section{Materials and Method}

\subsection{The Growth of Urban Fringe Area}

During the last decade, the urbanization on fringe areas has been one of the most important trends happen in the developed countries (Kivel, 1993). In Northern American, the migration of white middle class moving out of the city center flows to the fringe areas, seeking good environment and safer neighborhoods, called white flight phenomenon. Meanwhile, in 2000, 86\% of all Black Americans lived in metropolitan areas-nearly two thirds in the city center (Gilham, 2002). The urban fringe areas explosion causes the social segregation between the city center and the urban fringe. The outward movement of urban population to the fringe areas has considerable city center's role implication. The declining of residential densities in city center and fast growing settlement in the urban fringe area could boost the fringe area's role and replace the urban core as the main focus of urban activities. Fringe areas are segregated by income and race, prone to social conflicts. This phenomenonmakes city landscape inverted, and city grows onto the borderless city. From the economists point of view, the fringe area growth has been criticized not efficient used as municipal infrastructure which is potentially reducing food productivity. In fact, many people still wonder whether the urban sprawl growth is the sign of increasing economic vitality or an ecological threat. On the other hand, taxpayers might see the construction of the facilities itself. The infrastructure in urban fringe areas should not be taken as a priority, because it is only intended for a small number of people who do not want to live together in a dense urban area. They prefer to live in the fringe area, unfortunately. To serve this group of people, the municipal was forced to provide various urban amenities which require a huge cost.

The key difference of urban sprawl between that occurring in Indonesia and western countries is that is not triggered by the preference but because of land pricing disparity. In developed countries, people prefer migrate to the fringe areas looking for good environment. In the contrary, in Indonesia, people are forced to live on the fringe area because of high land prices in urban core. For the low income people there is no other choice. Living on the urban fringe area for dwellers means not only living on the heart of the city, but also on the edge of urban society (Jenks, 2000). The fringe area becoming the location of mixed enclave of settlements; namely planned settlements, unplanned settlements, and autonomous settlements; characterized by the sprawl development. All types of settlements located side by side and they grew simultaneously. This condition makes the fringe area has dualistic characteristics, mixed between modern society and traditional/rural society, urbanity and rurality, formal and informal. In the future this area will integrate to the urban core. The integration process will largely determine the future shape of cities.

\subsection{Method of the Research.}

The proper method to diagnose the problem of a city must started by recognizing the historical and social phenomena and then followed by the perspective to respect for local wisdom and indigenious urban characteristic. To obtain an authentic and original local wisdom cannot be done with the generalization manner. Therefore the research should be run with qualitative approach within naturalistic paradigm umbrella. Grounded theory method is choosen because could reveal the tacit knowledge upon the form of concept that is able to explain the settlement growth phenomena in the fringe area that has not 
been identified completely and has not had theoretical knowledge explaination comprehensivelly. Western theories of urban fringe areas still leave many questions and blow a prolonged debate. This method also can give the intricate details phenomena that difficult to solve with some quantitative methods (Strauss,1990).

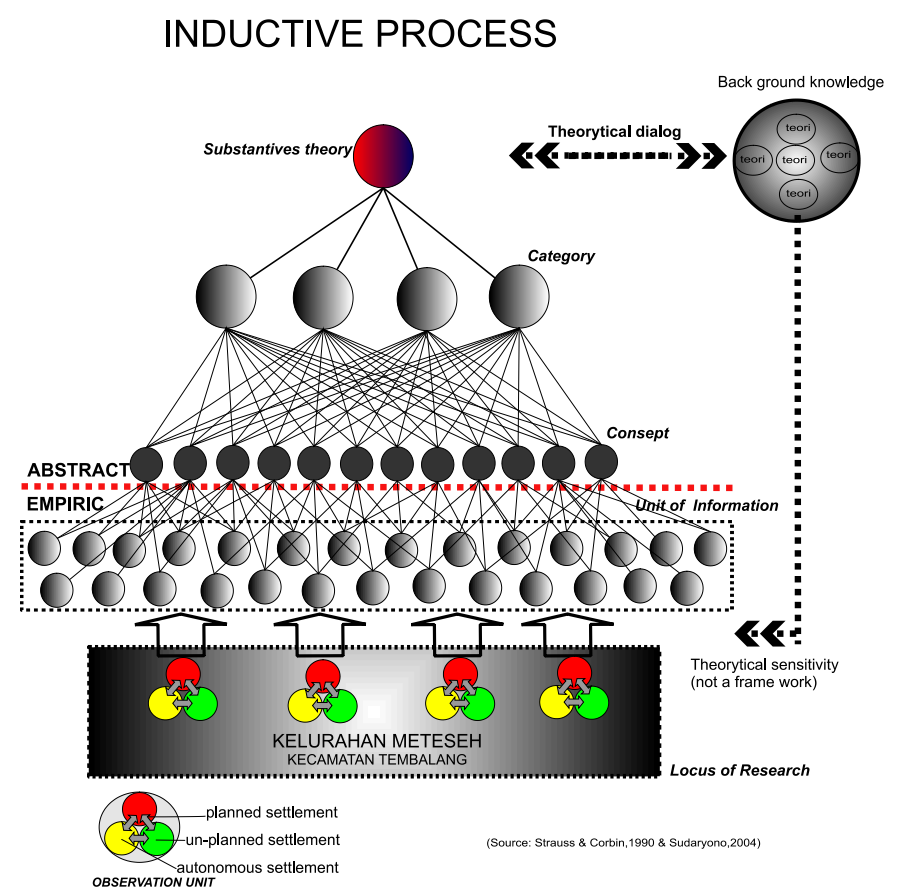

Fig 1: Inductive Process

Source: Straus and Corbin, 1990 \& Sudaryono, 2004

There are four main stages in building the local knowledge of the field, [1] coding [2] concept, [3] categories, [4] theory. The step of theorizing data can be broadly described as follows: Coding is the process of analyzing data, while concept may appear as conceptual labels placed on discrete happening events, and other phenomena. Category is a classification of concepts. This classification is discovered when concepts are compared one againts the others and appear to pertain to a similar phenomenon. Thus, the concepts are classified onto the higher order than abstract concept which called category. Conceptualizing data with grounded theory model starts from labeling the discrete phenomena which called coding, followed by building a concept using interpretive procedures. The interpretative procedures are a base to formulate the categories and theories. These procedures include the techniques for conceptualizing data can be seen schematically in Figure 1.

This procedure give the advantageous to determine the accuracy and distinctiveness concept of theorising data. The first level of abstraction results in concept as well as the main component is forming a theory. Concept itself is emerged, has to be built not presented naturally.

The next step is to build multiple categories at a higher level of abstraction, from a number of interlocked concepts. From some of the tentative categories, one will be selected to construct a substantive theory. 


\section{Result and Discussion}

\subsection{General Condition of Semarang}

Semarang city is the capital of the Central Java Province. It is located in the middle of Java Island, on the north coast. Semarang has a strategic location on the main national transportation corridors between Jakarta and Surabaya. In 2010, Semarang consisted of 1.592.632 inhabitants, and had growth rate $1.90 \%$ per year. By having 37.366 hectares of the administrative area, and the gross density is 43 inhabitants per hectare; unfortunately Semarang does not have an advance level of population growth.
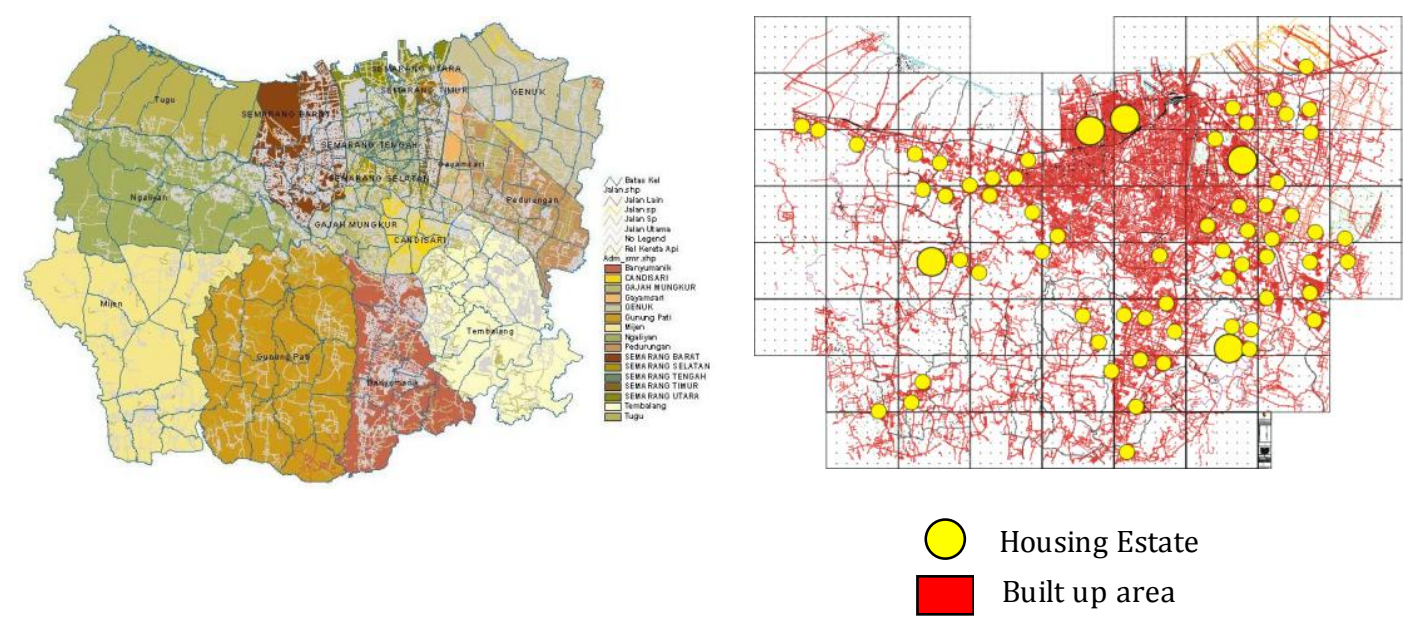

Figure2. Map of Semarang city, 2009

Source: Semarang Local Planning Development Agency

According to the study conducted by the "Department of Human Settlements and Regional Infrastructure" (2003) for urban and suburban areas of Semarang city, it can be said that urban sprawl in Semarang is fuelled more by fast growing housing estate as an impact of abundant housing supply (Fig.2). Based on 2007's statistical data the city centre has a negative population growth rate while urban fringe areas have high percentage. The condition demonstrated that partly of inhabitants moved out from city centre to the fringe areas. During 2002-2007 the population of city centre tended to decrease while urban fringe areas are increase. Unstructure urban sprawl scattered in fringe areas like archipelago of enclaves. Physically, fringe areas consisted of three types of settlement. First type is planned settlement developed by housing estates which mostly occupied by middle and high income groups equipped with luxurious urban amenities. Second type is indigenous rural settlements grew in natural pattern; there are lack of urban services and have been categorized as un-planned settlements. Third type is autonomous settlement consists of mixed settlement and shopping facilities. All type of settlements located side by side and grew simultanously.

Due to the irregular growth, spatial expression in the suburbs becomes chaotic. New housing estates are not only occupying vacant areas or paddy fields but often oc cupy the existing traditional rural settlements. The growth of this area is followed by the emergence of an individual settlements built in order to take advantage of public and social facilities which have been built by the developer. This phenomena poten tially rising a social conflict. 


\subsection{Locus of Research}

This research conducted in Kelurahan Meteseh - Tembalang District, one of the fastest growing urban fringes in Semarang city. The research area consists of three types of settlements i.e planned settlement in the form of housing estate called Permukiman Bukit Kencana Jaya, traditional rural settlement in the form of Rejosari hamlet and autonomous settlement in the form of Kedungwinong hamlet (Fig.3).

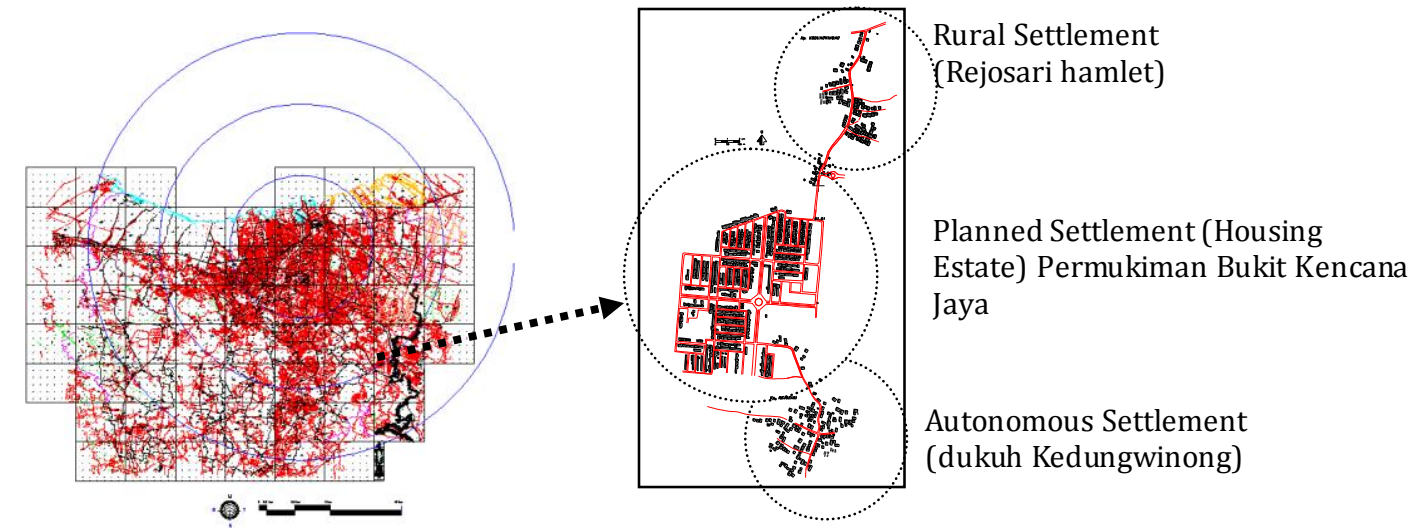

Figure 3: Locus of research

Source: Semarang Local Planning Development Agency

Generally, Permukiman Bukit Kencana Jaya fulfilled by the middle class inhabitants,meanwhile the rural settlements is inhabited by low social strata. The autonomous settlements lived by people with a social strata mixture indeed(Fig.4). Those three types of settlements above lies side by side, one another have an impact on the inhabitant's interaction. To reach the Rejosari hamlet must pass through the Permukiman Bukit Kencana Jaya and the Kedungwinonghamlet
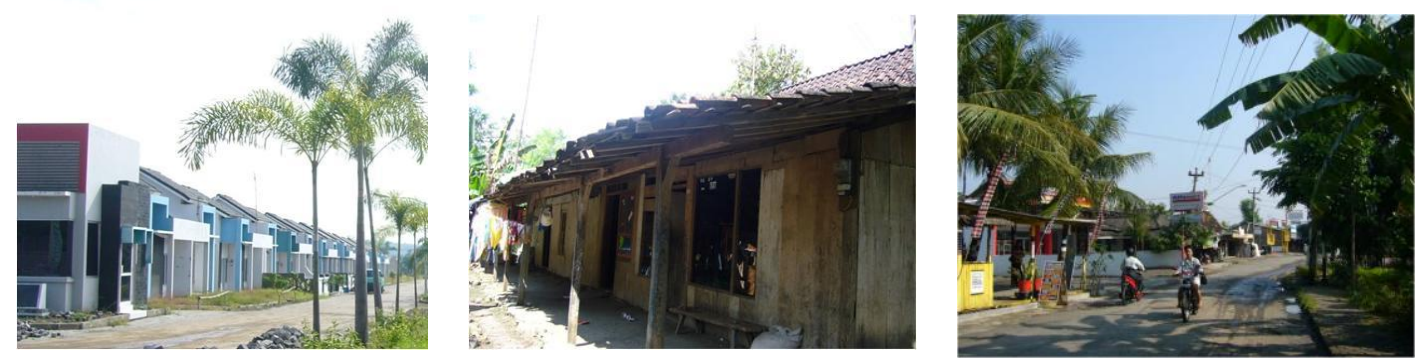

Figure 4: Planned, Un-planned and Autonomous Settlement Source: Field Survey 2009

Bukit Jaya Kencana Jaya settlement built in 1990 and inhabited in 1992. This settlement is dominated by the types 36 and 45. Most of the inhabitants work as employees and civil servants. The premium type is placed on the main road until now has not been fully filled. Although the developers had taken control of land use permits more than 300 ha. The difficulty to obtain the drinking water supply becomes determinant factors for developers to develop bigger housing estate. Therefore, developers tend to build shopping complex.

Rejosari hamlet- a rural settlement- lies adjacent to Permukiman Bukit Kencana Jaya, has organic pattern follows the hilly topography. Most of its inhabitants have a low socio economic strata. The arrival of newcomers with higher social economic level rising 
the income opportunity.Many of Rejosari dwellers becoming vegetable vendors and domestic workersworking on Permukiman Bukit Kencana Jaya. Observing from the physical aspect of the built environment is identified the emergence of spontaneous public space, in the form of market and street vendors. This space is used as a place for a gathering between the rural inhabitants and the dwellers of Bukit Kencana Jaya housing estate. This situation trigger the interdependence between the two types of inhabitant.Kedung Winong hamlet is a village that is located at the main road to the settlement of Bukit Kencana Jaya. Ten years ago, this surrounding area is sparsely populated.The emerged of spreading settlement in the surounding of Permukiman Bukit Kencana Jaya have boosted physical changing of Kedungwinong hamlet.

The increasing numbers of the population in this area are followed by an increased need for shopping facilities such as shops and stalls. Kedungwinong have a good acces to the many new settlements. Therefore, stalls and shops are growing fast, especially along the main road. Kedungwinong is now growing towards the modernity with the number of supermarkets and shopping complex (Fig.5).

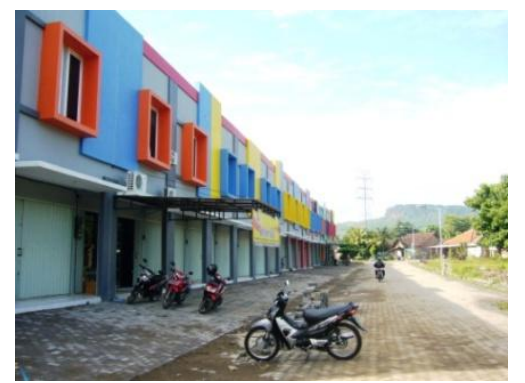

Figure 5: Bukit Kencana Jaya Housing Estate

\subsection{The Local Wisdom of the Urban Space Integration in Kelurahan Meteseh}

After making a series of grand tour and followed by mini tour the next step is an effort to to discover numbers of discrete phenomena which are associated with focus of the research. After conducting intensive observations in the area of research and behave as a native inhabitants, discovered twenty five units of information. In this study, the discrete phenomena that occurred in the research rea called the unit of information. It would be "read in depth" to understand the meaning, what beyond the facts that appears in the field. Social phenomena very often cannot be understood in terms of what was said and done, therefore, researchers must be able to act as a key instrument, to describe, analyze and construct the social phenomena into a solid concept of meaning (Nasution, 2003). Therefore we need a thick and deep description which has capability to reveal the phenomena associated with what is actually happening, what people thought happened and what they think should be happen. Building a local concept is preceded by a conceptual label attributed to the events, incidents or other discrete phenomena. The Concept is closely allied with conceptual labels are grouped, then broken down into different parts oc the trait, compared to the differences and similarities.

Having discovered twenty five units of information, the next step is analysis process, in grounded theory is called coding.There are four activities prior to the coding process, namely: labeling, sorting, recording and interpretation. Labeling refers to the concept of the incidents and phenomena in permukimam Bukit Kencana Jaya, the Rejosari hamlet and the Kedungwinong hamlet.Sorting means the comparison of one label to 
another based on a characteristic combination and sequence and then dividing into the group. Sorting refers to the comparison features a label with another label to determine the grouping based on a combination and sequence characteristics. Incidents and events that have specific characteristics in different forms of social situations associated with a theory that will be developed; commonly referred to as discrete phenomena; used as a theoretical sample.The recording is a product of writen coding and open as a material for reflection and abstraction. Interpretation refers to the relationship character in terms of abstraction in order to understand the dimensions label system. The next step is analyzing. In grounded theory method, analysis is called coding. Coding at this stage is called open coding which means the process of outlining, examining, comparing, conceptualising, and categorising data (Strauss, 1990).

After the open coding was performed on twenty five discrete phenomena, only eleven abstract concepts emerged. In the next step is the axial coding - aset of procedures whereby data are put back together in new ways after open coding, by making connections between categories. This is done by utilizing a coding paradigm involving conditions, context, action strategies and consequences. From the eleven concepts of urban space, analysis tends to convergent leads to three conceptual categories, namely: collaborative space, divided space and community space.

The next step is selective coding -the process of selecting the core category, systemically relating it to other categories, validating those relationships, and filling in categories that need further refinement and development. Core category - the central phenomenon around which all other categories are integrated - is the basic concept of the three conceptual categories of urban space that had been developed before. The collaborative interaction is the core category.

By doing all the necessary stages in the inductive process as previously described, this method successfully reveals the local wisdom that is the basis of integration of the three forms of settlements on the fringe area of Semarang city. The local wisdom is a concept of collaborative interaction.Collaborative interactions that occurredin the three groups of entities is reflected in the social order.Although physically the study area is divided into three parts but socially is one unit (Fig. 6). Fragmentation of the physical space into three variants (unplanned settlements, rural settlements and autonomous settlement) is not identical to the social structure configuration.

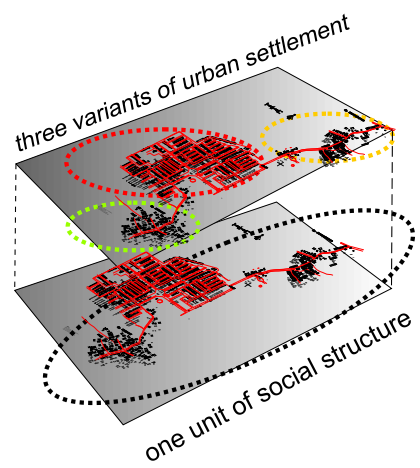

Figure 6: Superimpose of physical space and social space in Kelurahan Meteseh Source: Data Analysis. 2009 


\section{Conclusion}

Discussion above has revealed the existence of local wisdom for the integration of urban space in the Kelurahan Meteseh Kecamatan Tembalang which is located on the fringe area of Semarang City. The local wisdom is the basic concepts of interaction characterized by collaboration. Local wisdom that emerged from the study of the social situation in locus of research, comprises in three concepts: [1] The behavior of urban space actors; [2] setting of urban space and [3] interdependence between actors of urban space.

This research has succeeded to revealed the local wisdom about how the integration of space in the fringe area takes place through collaborative interactions among three groups of entities, who live in housing estates, rural settlements and autonomous settlements. Interaction is done by using two mechanisms of adaptation approaches that instinctively made by rural inhabitants to remain able to survive in an increasingly narrow social spaces. The first approach is territoriality-the way to manipulate the environment settings that have been formed by building a new social spaces, to achieve optimal safety and comfort. The second approach is by enhancing its own capabilities. The urban actors perceive the crowdedness as an inconvenience. The presence of others in large quantities, limiting the freedom of movement and arising inconveniences. Thus the urban actors need to reset their cognitive structure to build awareness of the need to be tolerant, kinship and easy to build consensus. This will make it easy to build a new positive perception of the presence of other people around him.

\section{References}

Bogart T, William. 2006. Don't Call It Sprawl. Metropolitan Structure in the Twenty-First Century. Cambridge University Press. New York.

Bruegmann, Robert. 2005. Sprawl: a compact history. The University of Chicago Press, Ltd. USA.

Dieter Evers, Hans \& Korff, Rudiger.2000. Southeast Asia Urbanism: The Meaning and Power of Social Space. LITVerlag.

Setioko, Bambang. 2010. Integration of Urban Space on Kelurahan Meteseh - the fringe area of Semarang. Doctor Dissertation. Faculty of the Graduate School - Diponegoro University.

Soja, W.Edward. 2005. Postmetropolis, Critical studies of Cities and Regions. Blackwell Publishing.USA.

Strauss, Anselm \& Corbin, Juliet. 1990. Basics of Qualitative Research. Sage Publications, Inc. California-USA.

Muhajir, Noeng. 2000. Methode Penelitian Kualitatif, Edisi IV (Qualitative Research Method). RakeSarasin. Yogya. 